\section{Use and Misuse of Science}

Is his presidential address "The Use and Misuse of Science" to the Royal Society of New South Vales, which has been reprinted in part from the Journal and Proceedings of the Society, Prof. J. C. Earl points out that control over Nature involves not merely the knowledge that in certain circumstances a known natural phenomenon will occur, but also the ability to arrange the stage so that the occurrence takes place when and where we will. Knowledge may be power, but it remains inactive until a conscious effort is made to use it. WVe can use the power we have constructively or destructively, and this re. sponsibility cannot be regarded lightly. Our conduct must be determined by some motive and the moral issue cannot be evaded. Discussing the use of science, Prof. Earl termed research associated with the use rather than the extension of knowledge, secondary scientific research, in contrast to primary scientific research, which is concerned with the extension of knowledge as such. The latter he considered an essential duty of a university, the discharge of which would foster its other duty of maintaining cultural traditions. He urged that the tendency to foster secondary rather than primary research in the universities of Australia with the resources now available was dangerous and that the claims of the latter required more energetic support from within and without. In urging this larger and keener interest in fundamental work, Prof. Earl did not suggest, however, that secondary scientific work was less important, and he referred to the need for scientific work in Australia on Australian products.

\section{Mental Disease and War}

IN a recent essay (Hibbert $J ., 37,513$; 1939) on mental disease as a factor in the causation of war, Dr. Olof Kinberg, professor of forensic psychiatry at the University of Stockholm, remarks that though it is growing increasingly clear that war as a means of solving social problems is utterly futile, for the remedy is worse than the disease, many large countries are seeking to imbue even their children with an admiration for war and to do all they can to represent it as the most glorious exposition of national greatness, while other countries are making every possible effort to avoid war, though they are compelled to build up enormous armaments. Prof: Kinberg discusses some of the psychological features of modern society which may help to explain this paradoxical state of affairs. He points out that in order to mould public opinion the ruler must-transform private citizens into a psychological mass and keep them in that condition for a considerable time. The production of this mass is brought about by the Press and the radio being in the hands of the Government, the formation of a bulwark against criticism and the persecution and destruction of anyone who dares to entertain different opinions.

Prof. Kinderg directs attention to the likeness between the qualities of the national mass and the paranoid personality which is characterized by touchiness, egoism, quarrelsomeness, inability to judge its own affairs impartially and a conceit and arrogance which sometimes takes the form of megalomania. At the same time the mass adopts towards its leader, however shabby and obscure his past may be, an attitude of servile submission which contains a strong infusion of magic and mysticism. A continuous interaction takes place between the national mass, whose passions are kept at boiling point, and the leader; who has himself shown from the onset abnormal psychical features of a paranoid character. Such a state of affairs, according to Prof. Kinberg, has been exemplified from the French revolution down to the revolutions of the present day.

\section{Eiderdown Industry and Protection of Eider-Ducks}

The numerous islands which border the north coast of the Gulf of St. Lawrence have long been a breeding ground of eiderducks. But it is only since 1933 that a supervised industry in the collecting and marketing of eiderdown has been established. During the past six years the export of cleaned eiderdown has increased five-fold, and the recognition of the value of the birds has led to active protection and encouragement of an increasing stock of nesting ducks. Whero the eiderdown industry has been established sovere penalties aro enforced for their destruction or molestation. The collection of the down, it is reported by the Office of the High Com. missioner for Canada, does not interfere with the regular hatching of the eggs, and as a result of this and of protection the colonies of eiders have been steadily increasing in numbers. For the purpose of eiderdown production, residents of the Gulf-shore area now lease from the Province of Quebec suitable coastal islands at a nominal rental for a period of five years, and each lesseo is supplied with a permit under the Migratory Birds Convention Act authorizing him to collect, possess and sell eiderdown taken from the nests in his leased area. We trust that a close watch will be kept upon this new industry and that definite counts will be made by scientific observers at periodic intervals to test the effect of the trade upon the number of birds. The conditions of the leases granted to the down collectors are unknown to us, but it is hoped that some provision is made to check what might casily develop into ruthless destruction at the close of a period of lease, if the lessee suspected that renewal might not bo granted.

\section{Re-organization of the Cotton Industry}

THe Cotton Industry (Reorganization) Act, which has since reached the Statute Book, is the subject of a further broadsheet issued by P E P (Political and Economic Planning). The Cotton Industry Board to be appointed by the Board of Trade will be representative of all sections of the industry in addition to having three independent whole-time members, including the chairman, with special knowledge of the industry. The Board will appoint, partly from among its own members, a special Export Development Committee, which will have the particular 